\title{
JUURNAL.RU
}

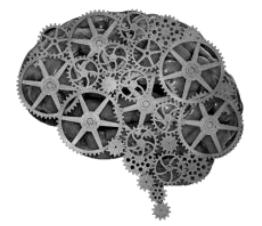

COMPANY GROUP "INTELLEKT"

\author{
Володарская Е.Б., Печинская Л.И. \\ Санкт-Петербургский политехнический университет Петра Великого \\ Санкт-Петербург, Россия
}

doi: 10.18411/lj2016-8-2-03

idsp 000001: lj2016-17-2-03

\section{Персонифицированный подход как современное требование Концепции Федеральной целевой программы развития образования на 2016 - 2020 годы}

В современном информационном обществе информационные технологии стали катализатором оптимизации учебного процесса. Суть этого процесса состоит не только в принятии новых технологий и изменении способов обучения, но и в осознании того, что ценности в мире постоянно меняются и, поэтому, чтобы оправдывать ожидания как будущих специалистов, так и работодателей, образование должно меняться. Таким образом, именно глобальная конкуренция, влияя на качество образования, позволяет государству получить и сохранить лидирующие позиции на рынке.

Поступательное нарастание инновационных процессов в экономике, промышленности и замедленный переход системы подготовки специалистов на инновационный путь развития, по мнению многих, вызывает необходимость реформирования системы высшего образования [8], что и призвана решить Концепция Федеральной целевой программы развития образования на 2016 2020 годы.

Данная Концепция определяет цели и задачи, направления и мероприятия, средства и этапы реализации перспективной программы развития Российского образования на всех уровнях, исходя из требований концепции долгосрочного социально-экономического развития Российской Федерации на период до 2020 года. Главной целью программы является перспектива наиболее эффективного развития образования в России, которая должна быть направлена на «формирование конкурентоспособного человеческого потенциала», способного 
реализовываться на национальном и мировом уровне. Одними из существенных направлений в реализации программы являются решение вопроса об оценке качества образования, создание условий для реализации индивидуальной траектории развития учащегося и упор на социальную ориентированность мероприятий, что предполагает использование персонифицированного подхода [6].

Процесс персонификации - это стремление человека быть самим собой. Успешно протекающий процесс персонификации усиливает интегрированность личностных структур, увеличивает степень позитивности, эмпатичности и конгруэнтности (К.Роджерс) человека, способствует повышению степени аутентичности человека, то есть соответствия его личности и сущности [7].

Понятие «персонификация образования» ученые трактуют как особую форму организации образовательного процесса, учитывающего особенности индивидуальных различий обучающихся (Е.И.Огарев); одно из направлений модернизации системы непрерывного профессионального образования (Е.А.Мелехина); процесс, направленный на развитие способностей и интересов учащихся (И.Э.Унт); фактор развития познавательной активности обучаемых (И.М.Осмоловская); средство построения индивидуального образовательного маршрута (В.Г.Ерыкова). В.Г.Онушкин рассматривает персонификацию образования как дидактический принцип, согласно которому содержание и все другие элементы образовательного процесса должны определяться и строиться исходя из интересов, потребностей и устремлений лиц, вовлеченных в учебную деятельность [2].

И. С. Казаков под персонифицированным обучением понимает такой личностно-ориентированный процесс обучения, который позволяет постоянно контролировать текущие изменения у учащихся, этот процесс направлен на максимальное усвоение знаний, формирование компетенций и развитие личности, которое базируется на стремлении к самоактуализации и саморазвитию [5].

Персонифицированный подход выражает требование предоставлять обучаемым варианты образовательных программ, маршрутов, видов образовательных услуг для выбора, осуществлять обучение по индивидуальным образовательным траекториям в соответствии с возможностями личности, 
изменяющимися потребностями, карьерными перспективами. Реализация данного подхода позволяет опираться на внутренние ресурсы личности обучающегося, разрабатывать перспективные проекты профессиональноличностного роста будущего специалиста [Галкина].

Большинство ведущих европейских и американских университетов развивают персонифицированную систему образования, которая выражается, с одной стороны, в индивидуализации, в предоставлении студенту полной свободы в выборе содержания образования и методов его освоения, с другой стороны, в опоре на дивергентное мышление студентов, которое позволяет им осуществлять многовариантный подход к рассмотрению образовательных и творческих проблем. В российской же системе высшего образования, которая целиком ориентируется на европейские и американские стандарты, существенно снижается эффект имеющихся во многих российских вузах персонифицированных подходов, т.к. во-первых, вводятся экономические «инновации» (нормативно-подушевое финансирование, растущие учебные нагрузки на преподавателей, сокращение («оптимизация») профессорскопреподавательского состава и др.), во-вторых, не учитывается менталитет российского человека, который значительно отличается от менталитета западных стран.

По мнению В. Ф. Габдулхакова, перспективы и эффективность персонифицированного образования определяются мультипарадигмальным подходом, предполагает открытость различным видениям проблемы прогнозирования и проектирования будущего высшей школы, обоснование инновационных стратегий развития высшего образования в концептуальном синтезе из множества образовательных парадигм; направленность на практический результат применения преобразующих стратегий и инновационных технологий к разным видам педагогических практик и разным моделям высшего образования; выявление приоритетов инновационных стратегий в формировании единого образовательного пространства в современном мире [1;58].

Традиционное высшая школа во многих странах столкнулась с проблемой уменьшения финансирования, что привело к возрастанию стоимости образования для студентов, т.е. большинству вузов приходится перестраиваться 
и адаптироваться к новым реалиям. А для потенциальных работодателей все большее значение имеет не диплом, а то, с какими умениями и навыками выпускник выходит из стен университета. Рейтинговые вузы уже давно заметили эту тенденцию и внесли изменения в образовательные программы, сокращая аудиторную нагрузку на теоретические дисциплины и увеличивая количество часов на практические занятия, различные виды практик и реальные бизнес-проекты на старших курсах обучения.

Однако скорость изменений на рынке труда такова, что без дополнительных курсов и параллельной работы по применению полученных навыков невозможно устроиться на высокооплачиваемую работу. К тому же и те, кто давно получил диплом по той или иной специальности, продолжают учиться, чтобы приспособиться к быстро меняющемуся миру. На этом фоне растет популярность бесплатных онлайн-курсов и более доступного платного онлайн-образования, что еще более ужесточает конкуренцию на образовательном рынке. Так, что выпускник вуза с теоретическими академическими знаниями значительно проигрывает специалистам с опытом работы и желанием учиться новому [3].

Таким образом, необходимо пересмотреть как образовательные программы высшего образования, так и подходы к реализации обучения студентов, чтобы повысить конкурентоспособность будущих специалистов на рынке труда. Персонифицированность образования поможет студентам еще на этапе обучения в вузе научиться принимать правильные решения для реализации своего потенциала, т.к. данный подход предполагает возможность выбора студентом подходящих лично ему инструментов обучения, выбора предметов и объема получаемых знаний, т.е. происходит адаптация курса к потребностям каждого студента, его сильным и слабым сторонам по мере изучения предмета.

Адаптивность повышается за счет онлайн-занятий, использования аудиоматериалов, обучающего видео, различных тестов. В будущем каждый студент будет сам создавать программу обучения и выбирать преподавателей и курсы, а в учебные заведения будет приходить, чтобы сдавать обязательный минимум знаний для получения необходимых сертификатов. 


\section{Литература:}

1. Габдулхаков В. Ф. Персонификация профессиональной подготовки в вузе: компоненты педагогической технологии: монография / В. Ф. Габдулхаков. - М.: Московский психолого-социальный ун-т (изд-во НПО «МОДЭК»); Казань: Казанский (Приволжский) федеральный университет, 2013. - 293 c.

2. Галкина, Т. Э. Персонифицированный подход в системе дополнительного профессионального образования специалистов социальной сферы: диссертация ... доктора педагогических наук : 13.00.08 / Галкина Татьяна Энгерсовна; [Место защиты: Рос. гос. социал. ун-т].- Москва, 2011.- 341 с.

3. Главные тренды в образовании 2016/ Eduget. URL: http:// https://www.eduget.com/news/glavnye_trendy_v_obrazovanii_2016-815 (дата обращения: 25.08.2016).

4. Грачев В.В. Персонализация образования в условиях глобального перехода к веб-стилю жизни // Экономика образования. 2012. №1. URL: http://cyberleninka.ru/article/n/personalizatsiya-obrazovaniya-v-usloviyahglobalnogo-perehoda-k-veb-stilyu-zhizni (дата обращения: 20.08.2016).

5. Казаков И.С. Проектирование персонифицированной модели обучения в вузе // Ярославский педагогический вестник - 2011 - № 3 - Том II (Психолого-педагогические науки). URL: http://vestnik.yspu.org/releases/2011_3pp/32.pdf_ (дата обращения: 20.08.2016).

6. Концепция Федеральной целевой программы развития образования на 2016 - 2020 годы. URL: http:/government.ru/docs/16479/ (дата обращения: 20.08.2016).

7. Орлов А. Б. Личность и сущность: внешнее и внутреннее Я человека // Вопросы психологии. - 1995. - № 2

8. Проблемы научно-исследовательской деятельности преподавателя высшей школы. / И.Ф.Албегова, М.Н.Гаранина, Г.И.Ибрагимов, У.А.Казакова, В.В.Кондратьев, Ю.М.Кудрявцев, Л.В.Редин, В.Е.Уткин, Ю.В.Уткин; под ред. В.В.Кондратьева. - Казань: Редакционно-издательский центр, 2012. C. 5. 